\title{
Philhellenism as a Regime of Forgetting: The Norwegian Archaeologist Ingvald Undset and His Report from Greece
}

\author{
Christine Amadou, University of Oslo
}

\begin{abstract}
A B STRACT
Taking the work of the Norwegian archaeologist Ingvald Undset (1853-93) as a starting point, this essay invites us to rethink European philhellenism, and its concomitant neoclassicist tendencies, as a distinctive "regime of forgetting." Discussing responses to Greece and Greek history from diverse contexts, it also explores how, in different cultural spheres, different "layers" of Greek history were forgotten, suggesting that, just like regimes of remembering, "regimes of forgetting" can be highly situation dependent.
\end{abstract}

n her autobiographical novel, The Longest Years, Sigrid Undset (1882-1949), a Norwegian winner of the Nobel Prize in literature, recalls how her father, the archaeologist Ingvald Undset (1853-93), allowed her "to borrow the little terracotta horse from Troy which Schliemann had given him, because it amused him to think that his little baby was patting with her damp and podgy hands a toy which perhaps some Trojan child had caressed thousands of years ago. It was a rash impulse on his part, as the marks of cement on the horse's legs will testify to all time." Undset brought this terra cotta horse, along with other antiquities, to Norway after a visit to Greece and to Heinrich Schliemann and his family in $1883 .{ }^{2}$ Undset, an internationally acclaimed archaeologist,

1. Sigrid Undset, The Longest Years, trans. Arthur G. Chater (New York: Knopf, 1935), 11: "Den lille terracotta-hesten fra Troja, som han hadde fått av Schliemann lot han Ingvild få låne, fordi det moret ham å tenke, her klappet hans lille unge med lubne, svette hender på en leke, som kanskje et barn i Troja for nogen tusen år siden hadde kjælt for. Det var et letsindig innfall av ham, som limingene på hestens ben siden i all fremtid utviste" (Sigrid Undset, Elleve aar [Oslo: Aschehoug, 1934], 12). Ingvild is Sigrid's pseudonym in the novel.

2. For Undset's collection of antiquities, see Siri Sande, "Ingvald Undset as a Collector of Antiquities," Acta ad archeologiam et artium historiam pertinentia, ed. Laszlo Berczelly and J. Rasmus Brandt (Rome: Giorgio Bretschneider editore, 1997), 57-76.

History of Humanities, Volume 5, Number 1. https://doi.org/10.1086/707696 (C) 2020 by Society for the History of the Humanities. All rights reserved. 2379-3163/2020/0501-0009\$10.00 
was the author of a study of the Bronze Age in Hungary, published in French (1881). ${ }^{3}$ His doctoral thesis - on the beginning of the Iron Age in Northern Europe- had been published in 1880, and its German translation had been received enthusiastically in Germany. ${ }^{4}$ Undset belonged to a generation of Scandinavian archaeologists whose pioneering findings and methods were received with the greatest interest in the rest of Europe. It is telling that Undset himself went as far as to write that "archaeology was born in the North," in a report of the archaeological conference held in Stockholm in $1874 .{ }^{5}$ Ten years after his return from Greece, Undset passed away, scarcely forty years old, most likely as a result of tabes dorsalis (syphilitic myelopathy) caught during one of his travels. ${ }^{6}$ Just before his death, Undset's travelogue, titled Fra Akershus til Akropolis (From Akershus to the Acropolis), was published. In this book, he describes his travels as well as his researches in various European museums and sites. ${ }^{7}$ It is also in this book that he relates how he visited Schliemann and his wife, offering the reader interesting glimpses into the almost parodic classicism of Schliemann's "Trojan mansion."

The present essay will use Undset's travel report to reflect on Western scholars' ambiguous involvement with Greece and to reflect on how Western philhellenism, which was all about revitalizing and recreating a lost past, was also a strong obliviating force. In Greece, the Ottoman and Turkish presence was a motivation for the Greek philhellene movement, and the memory of the centuries of Tourkokratia was maintained as

3. Ingvald Undset, Études sur l'âge de bronze de la Hongrie (Christiania: Cammermeyer, 1880)

4. Ingvald Undset, Das erste Auftreten des Eisens in Nord-Europa: Eine Studie in der vergleichenden vorhistorischen Archäologie, translated by Johanna Mestorf (Hamburg: Otto Meisser, 1882).

5. "thi Arkæologien er født i Norden: det er nordiske Videnskabsmænd som til alle Tider vil beholde Æren for først at have lagt det videnskabelige Grundlag for den arkæologiske Forskning, og det er fornemmelig deres Arbejder, som ude i det øvrige Europa have vakt Opmærksomhed og Interesse derfor" (Ingvald Undset, Den arkoologiske kongres i Stockholm [Christiania: Cammermeyer, 1874], 1).

6. See the entry "Undset, Ingvald Martin" in Studenterne fra 1871, ved deres 25 Aars Jubiloum (Christiania, 1896), 266-74, which was probably written by his wife Charlotte. However, the cause of death mentioned there, tabes dorsalis, was later questioned.

7. Ingvald Undset, Fra Akershus til Akropolis (Christiania: Alb. Cammermeyers, 1892). Akershus is the name of the old castle on a rock in Kristiania (the city's name was changed to Oslo in 1925).

8. While Undset writes with obvious fascination for Schliemann's career, his critical sense nonetheless remains awake. He points out that Schliemann's background as an autodidact and his uncritical enthusiasm were problematic, and also mentions his failure to bring his reading up to date: "The books that are the most valued and considered to be the most fundamental in the philological sciences, were scarcely used; [his library possessed] nearly everything from the most recent literature on the classical period, but whereas the strongly methodological works by the German philological school were uncut, the books in French and English, often popular and almost dilettantish things, had been carefully read." This part of Undset's book has been translated into English in From Akershus to Acropolis: Norwegian Travelers to Greece, ed. Christine Amadou and Jorunn Økland (Athens: Det norske institutt i Athen, 2019), 33-39. 
part of a collective, national identity. But when it comes to the Western, that is, nonGreek philhellenism, we see how there was, among Western scholars and key players in the cultural world, a significant willingness to actively and voluntary forget all Ottoman cultural contributions to the culture the philhellenes met in contemporary Greece.

As one particular form of classicism, defined as an aesthetic movement drawing on ancient Greek models, Western philhellenism thus represented what we can call a selective conception of history. We can see this clearly in Ingvald Undset's attitude toward Greece: On the one hand, he was deeply affected by the physical remains he foundsuch as the terra cotta horse - as well as by the idea of a spiritual continuity between classical antiquity and his own world. On the other hand, he also felt dépaysé and troubled by the strange and Turkish presences in Hellas, in the free Greece he visited at the end of the nineteenth century. His position oscillated between philhellenism and misohellenism - a recurring conflict in contemporary travel reports. ${ }^{9}$ Philhellenism typically insisted on the continuity between antiquity and contemporary Greece, while misohellenism insisted on the "mise en cause des grecs libérés." scholars remained armchair scholars, it was unproblematic to sideline the history between antiquity and their own days. But from the mid-nineteenth century onward, a growing number of Westerners left their studies in order to visit the historical sites in Greece. ${ }^{11}$ In 1894, the French traveler Gaston Deschamps (1861-1931) introduced the word mishellénisme, born out of the "discrepancy between what one expected from Greece, and what Greece was in reality." 12 Undset's written impressions are strongly colored by the tradition of European travel diaries, but they also represent a number of original features, since he was one of the first Nordic professional archaeologists to report on a journey to Greece. ${ }^{13}$

9. For a discussion of these ambiguities, see, for instance, Sophie Basch, Le mirage grec: La Grèce moderne devant l'opinion française (1846-1946) (Athens: Kaufmann, 1995).

10. Gilles Grivaud, "Introduction au(x) mishéllenisme(s)," in Les mishellénismes: Actes du séminaire organisé à l'École française d'Athènes (16-18 mars 1998), ed. Gilles Grivaud (Athens: École française d'Athènes, 2001), 2.

11. See Fani-Maria Tsigakou, The Rediscovery of Greece: Travellers and Painters of the Romantic Era (New York: Caratzas Brothers, 1981).

12. "De la disproportion entre ce qu'on attendait de la Grèce, et ce qu'elle était en effet, naquit alors le mishellénisme" (Gaston Deschamps, La Grèce d'aujourd'hui [Paris: Armand Colin, 1894], 376). The phenomenon of misohellenism is discussed by means of case studies in Grivaud, Les mishellénismes.

13. Printed reports of travels to Greece undertaken by Norwegians before Undset include, to the best of my knowledge, only the following travelogues: Christian Bugg's Fra Grokenland (Christiania: Jenssen, 1860); and the art historian Lorentz Dietrichson's Paa Studierejser: Albumblade og Optegnelser (Christiania: Cappelen, 1876). 


\section{CLASSICISM, PHILHELLENISM, MISOHELLENISM, AND THE ROLE OF FORGETTING}

This contribution will focus on the imagined continuity between ancient and modern Greece, an idea that emerged in the nineteenth century through a dynamic interplay between Western scholars and Greek nationalists and that implied a self-imposed forgetting (Vergessenwollen) of Turkish historical realizations and their impact on learning and development throughout the four hundred years of Turkish rule over Greek territories. I will explore how this type of oblivion, which is inherent to the classicist paradigm, shaped Undset's response to Greece, resulting in a tension between the inherited assumption of historical continuity and a concomitant refusal to accept intermediate layers of history. What was the background to this classicist regime of scholarly amnesia?

In the North, German scholarship set the tone in Undset's time. In Germany, a growing anti-Latin classicism, underlying anti-French and anti-Catholic ideologies, may have stimulated a shift of interest from the Roman to the Greek tradition and toward the exaltation of ancient Greece that is so characteristic of the German classicism of this period. ${ }^{14}$ Scholars and artists greatly admired Greece, often without ever visiting the country. Unlike Italy, Greece was considered to be dangerous territory, and this is why outstanding philhellenes like Johann Joachim Winkelmann (1717-68) and Johann Wolfgang von Goethe (1749-1832) never set foot on Greek soil. ${ }^{15}$ This lack of direct experience with the country in the formative years of German - and hence Europeanphilhellenism means that Greece could be regarded primarily as an ideal world and as the "cradle of Western civilization," detached from any specific geographical situation. Of course, this claim of ideal universality came with a cost: Western scholars tended to overlook the fact that the Greek legacy was also located in a specific region, consisting of several historical layers.

This tendency to abstract "Greece" (the ideal) from Greece (the reality) has ramifications in both academic and political discourse, and is permanently nourished by the interplay with Western scholars and artists, as we see from another example, Lord Byron's translation of the revolutionary hymn Thourios by Rhigas Feraios. ${ }^{16}$ The poem

14. The best expression of the German philhellenism must be the very title of E. M. Butler's book, The Tyranny of Greece over Germany (Cambridge: Cambridge University Press, 1935).

15. For the Germans' special love for Greece, see also Anthony Andurand, Le mythe grec allemand: Historie d'une affinité élective (Rennes: Presses Universitaires de Rennes, 2013); and Suzanne Marchand, Down from Olympus: Archeology and Philhellenism in Germany, 1750-1970 (Princeton, NJ: Princeton University Press, 1996).

16. Apostolos Dascalakis, "The Greek Marseillaise of Rhigas Velestinlis," Balkan Studies 7, no. 2 (1966): 273-96. 
was first written in 1796 as a free translation of the French Marseillaise into Greek, and was then translated by Lord Byron in 1811 as a "Greek War song," with its famous first line: "Sons of the Greeks, arise!"17 The song appealed for a struggle against the "Turkish tyrant's yoke" in imitation of old allies: "Hellenes of past ages." The next link in this chain of translation was the Norwegian version of Byron's text by the poet Henrik Wergeland. He called it "Nygræsk krigssang" (neohellenic war song) and the translation was explicitly "free."18 Wergeland probably did not recognize it as the Marseillaise, but he certainly recognized the Greeks' desire to return to the ancient models in order to build a new national identity.

Norway in the nineteenth century was a country with strong ties to this German tradition. Ingvald Undset's archive contains detailed college notes covering the lectures of the Hegelian philosopher Georg Vilhelm Lyng (1827-84) at the University of Christiania (present-day Oslo) in 1873. ${ }^{19}$ Unlike that of Oriental civilizations, Lyng argued, the unicity of Greece was not merely rooted in national characteristics: they were unique in that they created a "consciousness that the human being is a spiritual and free being." 20 Through the lectures of Lyng and his colleagues, Ingvald Undset was taught to see Greek culture as a common ancestor and as the start of the entire history and selfconsciousness of the West. When he traveled to Greece, this "un-national" spirit was what Undset expected, but hardly what he found.

The encounter between Western philhellenes and the real, geographical Greece has much in common with the confusion of Western travelers to the Orient, which Edward Said was the first to analyze. We see this parallel clearly in Said's analysis of the travel report of the French author Gérard de Nerval (1808-55), Voyage en Orient (1842), where Nerval describes his disappointment and confusion when he is confronted by the reality of his dreams, the physical Orient. ${ }^{21}$ But in the case of the travelers to Greece and the philhellenic movements, there are some distinct features that are closely connected to the history of Greece in the nineteenth century.

In the article "The Resilience of Philhellenism," George Tolias mentions three different forms of philhellenism, historically located before, during, and after the Greek

17. Lord Byron, "Sons of Greeks Arise," first published in Childe Harold's Pilgrimage: A Romaunt; and Other Poems (London: T. Davison, 1812), 223-25.

18. Henrik Wergeland, "Rhigas nygræske Krigssang (Frit oversat)," in Samlede skrifter 1, pt. 1 (Oslo: Cappelen, 2008). This "creative translation" was probably written around 1830.

19. Forelesninger over den antikke filosofis historie I, af Prof. Dr. G. V. Lyng, Ingvald Undset 1te Semester 1873, Undset archive, Nasjonalbiblioteket, privatsamlingen [National Library of Norway, Private archives], Oslo.

20. "bevidsheden om at et menneske er et aandeligt og frit væsen" (ibid., 2).

21. Edward Said. Orientalism: Western Conceptions of the Orient (London: Routledge, 1978). 
War of Independence. ${ }^{22}$ In chronological terms, Undset arrives in Greece in the third stage of philhellenism in Tolias's scheme, where "revival as national objective and the instauration of multiple bonds with the antique past were the keystones in shaping the identity of the newly founded Greek State." ${ }^{23}$ How did a Norwegian scholar adapt this "third-stage philhellenism," revitalizing the antique past in a national identity building project, when at the same time he felt the still strong presence of the Ottoman influences and was in search of a universal Greece? Undset believed in the Greek heritage as a common ground for all the European nations, as he had learned from his teacher Lyng at the University of Christiania. The presence of the classical ideals was stronger in Northern European countries than in Greece itself. His misohellenic attitudes can be explained by his confusion over the Turkish elements he encountered in Greece, which for him were a hindrance to the image of continuity between antiquity and contemporary Greece. Was it possible to impose a regime of forgetting on how the Ottoman period was still present in Greece? Was it possible to forget how the Ottomans had contributed to one phase of Greek history, in constructing monuments and traditions of their own, in adapting and, in some cases, erasing the country's ancient past?

"Funes el memorioso," a short story by Jorge Luis Borges, describes a system where the protagonist remembers everything. ${ }^{24}$ While Funes cannot help remembering every minute detail, he is incapable of grasping generalities and abstract ideas. Inversely, therefore, Borges's story demonstrates how the cost of remembering ideas consists in forgetting details. But just as a preoccupation with details can make one forget the whole, so too grand schemes can force significant details into oblivion. Accordingly, I would argue that systematic oblivion fundamentally underlies the idea of antiquity as a model. In other words, it is an essential part of the paradigm, and classical scholarship itself often assumes the idea that an unbroken continuity of a tradition needs to be reconstructed or even restored. This sense of continuity underlying classical scholarship implies the collective forgetting of agents, periods, and learning that do not fit in.

The renewed fascination with things Greek spread throughout Europe, and as a part of both the Romantic and the Enlightenment movements, it even reached the Greeks themselves. This happened inter alia through translations that finally reached the Greek minority in the Ottoman Empire by the end of the eighteenth century. ${ }^{25}$

22. George Tolias, “The Resilience of Philhellenism," Historical Review/La Revue Historique 13 (2016): 51-72.

23. Ibid., 68.

24. Jorge Luis Borges, "Funes the Memorious," in Labyrinths: Selected Stories and Other Writings, trans. Donald Yates and James Irby (1964; London: Penguin, 2000), 87-95.

25. One international bestseller was Jean-Jacques Barthélemy, Le Voyage du jeune Anacharsis en Grèce, dans le milieu du quatrième siècle avant l'ère vulgaire (Paris: Chez De Bure l'aîné, 1788), 
In the Greek struggle for independence in the early nineteenth century, strongly driven by Enlightenment ideas and by the prevailing philhellenic ideology, the active forgetting of the remaining heritage from the Tourkokratia became a substantial part of the new Greek national identity. ${ }^{26}$ In the introduction to his 1803 Mémoire sur l'état actuel de la civilisation dans la Grèce (Memoir on the present state of civilization in Greece), the Greek scholar and medical doctor Adamantios Koraï (1748-1833) wrote to a French audience: "We have all felt the need to regain possession of the civilization of our ancestors from whom we have been disinherited (so to speak) by a long series of misfortunes." ${ }^{27}$ For Korais, the Ottomans had left their stamp on the Greeks in the form of a number of undesirable characteristics, "the same as those we see in nearly all enslaved peoples." In his eyes, the contemporary Greeks were superstitious, weak, savage, and ignorant, but historical knowledge was propelling them toward a reborn selfconsciousness, encouraging them to declare: "We are the descendants of the Greeks, we should try to become worthy of that name once again, or else stop bearing it." ${ }^{28}$

Initially, Koraïs's interpretation of the Ottoman dominance as the basis of all objectionable aspects of contemporary Greek society worked well. The desire to forget Ottoman history in Greece (Vergessenwollen) led champions of Greek independence back to an idealized ancient past. ${ }^{29}$ But this enthusiastic atmosphere, where philhellenism and revolutionary nationalism went hand in hand, and which eventually led to Greek independence in 1832, could not simply do away with the many tangible cultural remains of Turkish rule, both in the form of buildings and in the presence of Muslim and non-Greek-speaking minorities. These elements were also a stumbling block to the visiting lovers of classical antiquity, even in the new and liberated Greece.

translated into grec vulgaire in 1797 by Doctor Sacellarius and published in Vienna. See C. Th. Dimaras, "Greece 1750-1850," in Perceptions of the Ancient Greeks, ed. K. J. Dover (Oxford: Blackwell, 1992), 203-25.

26. See the case study by Reşat Kasaba, "The Enlightenment, Greek Civilization and the Ottoman Empire: Reflections on Thomas Hope's Anastasius," Journal of Historical Sociology 16 (2003): 1-21.

27. "Nous avons tous senti le besoin de rentrer en possession des lumières de nos ancêtres, dont une longue suite de malheurs nous avait, pour ainsi dire, déshérités" (Adamantios Koraïs, Mémoire sur l'état actuel de la civilisation dans la Grèce, lu à la Société des Observateurs de l'homme le 16 Nivôse, an xi (6 Janvier 1803) [1803]). See also Giorgio Stamboulis, "The French Revolution and Greece, Four Pro-French Propaganda Writings of Korais," Giornale di Storia costituzionale, no. 25 (2013): 203-22.

28. "Nous descendons des Grecs, il faut tâcher de redevenir dignes de ce nom, ou ne plus le porter" (Koraïs, Mémoire, 60).

29. In the construction of Athens, we can even see some references to the Byzantine heritage, such as in the building by the Danish architect Theophil Hansen of an ophthalmological hospital in the Byzantine style near the classically inspired university building. But the Byzantine inspiration remained minor, probably because of the strong interest of the Germans in the ancient past. 


\section{UNDSET'S EXPERIENCE OF GREECE}

Ingvald Undset's From Akershus to the Acropolis describes his periods of residence in Rome, in northern Italy, and in Central and Northern Europe, many of which were related to his archaeological interest in the Northern Bronze Age. But his final visit to Greece represented the climax of his travels. The opening of the book makes clear which site he deemed to be the most significant of all those he visited: "So I was to have the opportunity to come to Greece," he wrote, "to step onto the classical soil of Hellas and to gaze at the Acropolis, with the most magnificent remnants from ancient times in all the world!" ${ }^{30}$ After this rhapsodic opening, Undset describes how he traveled from Brindisi to Greece, offering details of the investigations he undertook in Olympia. Judging from his diary, he was principally interested in Bronze Age fibulas and arm rings, which he scrupulously cataloged and drew in his notebook. ${ }^{31}$ Undset's drawings are specialized and in that sense far removed from the common travel diary tradition. Rather than drawing ruins, monuments, or panoramic views, he concentrated on the minutiae of small artifacts. But in the published book, largely written in his study in Christiania, he does offer literary impressions both of monuments and of contemporary Greece. These digressions demonstrate the assumptions and bias that strongly informed his view of Hellas.

His encounter with the Acropolis, for example, follows the topos known from earlier travelers. In his passionate description of the ruins of the temple, he returns to his general point, which is that he "could not for a single moment ignore the consciousness that this art was the most beautiful flower of this culture, that had as its conscious ideal the harmonious development of the beautiful human personality." ${ }^{32} \mathrm{He}$ did not feel a stranger, because he had been brought to the "cradle of the evolution he felt fortunate to belong to." ${ }^{33}$ All this shows his need to see Greece as the starting point of a general cultural evolution and as the beginning of Western civilization in its entirety. However, these universalistic ideas are accompanied by negative impressions of contemporary Greece. His description of the Athenians can serve as an example: "It was striking to notice how all the people in Athens were different externally from what we know as the classical types; there were some handsome, well-built men, but none of the pure,

30. "Saa skulde jeg da faa komme ogsaa til Grækenland, faa betræde Hellas' klassiske bund og faa skue Akropolis med verdens herligste oldtidslevninger!” (Undset, Fra Akershus til Akropolis, 1).

31. Undset, Notebook, Nasjonalbiblioteket Ms. $4^{0}$ 858:27.

32. "fordi jeg intet øieblik kunde se bort fra bevidstheden om, at denne kunst var den skjønneste blomst af den kultur, som havde sat som sit bevidste ideal den skjønne menneskelige personligheds harmoniske udvikling" (Undset, Fra Akershus til Akropolis, 65).

33. "vuggen for den udvikling, ogsaa han følte sig lykkelig ved at tilhøre" (ibid., 65). 
harmonious types that we call Greek; the people seems to be a somewhat degenerate, crippled race, with hard, irregular traits." ${ }^{34}$ In these lines, we can hear an echo of how the French traveler and archaeologist Edmond About (1828-85) experienced contemporary Greece about twenty years earlier after a visit to Athens as a member of the École Française d'Athènes. He oscillates between admiration for the classical past and disappointment with the present state of Greece. He wants to see an unbroken transmission, which Greece itself does not offer. Accordingly, in the book La Grèce contemporaine, About does not hide his own disappointment with his encounter with the "real" Greece: ${ }^{35}$ "The beauty of the Greek race is so celebrated and travelers so fully expect to find in Greece the family of the Venus of Milos, that they think they have been taken in when they arrive in Athens. The Athenian women are neither beautiful nor shapely; they have neither the lively physiognomy of Frenchwomen, nor the rich beauty of the Roman dames, nor the pale, white delicacy of the Turkish women. One sees nothing in the town but ugly creatures with broad noses, flat feet, and ill-formed waists." ${ }^{\text {36 }}$

About's ironic and satirical report provides an interesting glimpse of one way of combining admiration for the ancient land, on the one hand, with the awkwardness of the contemporary Hellenes, on the other. It is noteworthy that, even for the disappointed travelers, there is an unbroken transmission, but this is not to be found in Greece, but in Western Europe. This is strongly reminiscent of Nerval's position, analyzed by Said, who preferred the Orient of the Parisian opera to the geographical countries of the Middle East.

We find a similar ambiguity in Undset's travel report. In his book, the combination of philhellenism and misohellenism is accompanied by an equally ambiguous position vis-à-vis Orientalism. On the one hand, an important part of Undset's scholarly agenda consisted in detecting Oriental influences on preclassical Greek cultures. He devotes a considerable space to presenting Oriental influences in various forms, from the rich colors in Mycenaean culture to the ornamental elements in the Dipylon style: "We may... point out how Argos at an early date ... was the leader among the Greek art centers in

34. "Paafaldende var det os at lægge merke til, hvor racen her i Athen i sit ydre var forskjellig fra, hvad vi kjender som de gammegræske typer; der var nok smukke, kraftfulde mænd at se, men ingen af de renskaarne, regelmæssige, hvad vi kalder græske typer; folket syntes at bære præget af at være en noget forkommen, forkrøblet race, med kantede, uregelmæssige træk" (ibid., 60).

35. Edmond About, La Grèce contemporaine (Paris: Hachette, 1863).

36. "La beauté de la race grecque est tellement célèbre, et les voyageurs s'attendent si fermement à trouver en Grèce la famille de la Vénus De Milo, qu'ils se croient mystifiés lorsqu'ils entrent dans Athènes. Les Athéniennes ne sont ni belles ni bien faites; elles n'ont ni la physionomie spirituelle des Françaises, ni la beauté large et opulente des Romaines, ni la délicatesse pâle et morbide des femmes turques. On ne voit guère dans la ville que des laiderons au nez camard, aux pieds plats, à la taille informe" (ibid., 40). 
the transformation and Hellenization of the influences that were adopted from the Orient. ${ }^{37}$ But when it comes to contemporary Greece, he regards the Oriental presence as a foreign element that does not belong to Greece: neither to classical Hellas, nor to the independent modern state. What has to be removed is "the crust of un-culture that still to a large extent covers [the Greeks]" and is the natural result of centuries of oppression. ${ }^{38}$ This means that in the dialectics of forgetting/memory, Orientalism plays totally different roles regarding classical antiquity itself and in the nineteenth century, which was dominated by scientific racism and the fear of Turkish influence.

By this "crust," Undset understood the Ottoman and Oriental influences, under which the unbroken historical tradition and, consequently, the common European heritage was assumed to be hidden. Undset's report from Greece is consistently ambiguous. Together with his fellow traveler Anton Ræder from Christiania, he speaks openly of his fascination for the exotic elements of the Greeks: the strange food, the resinated wine, the colorful and unusual costumes. But this fascination did not alter his central conviction that these represented foreign elements in the Greek country. Liberation from "the crescent" implied a return to the classical forms, ideals, and type, basically a return to Northern European classicism. For Undset and many of his colleagues, there was no imaginable way of integrating the Ottoman legacy into Greek history. In their support for the Greeks' struggle for a "classical" identity, these scholars felt that influences from the new Orient deserved to fall into oblivion. Consequently, misohellenism can be understood as a state predating the ultimately successful forgetting of those elements that were considered incommensurable with a free and modern Greece.

\section{CONCLUSION}

Even today, both Greeks and Western scholars scarcely regard the Turkish traces in architecture, music, food, and dances as an integral part of Greek culture and identity. But these attitudes of overlooking, neglecting, or forgetting the Ottoman history are currently challenged. The Danish historian Trine Stauning Willert, for example, has recently published a substantial monograph that explores the Ottoman heritage in Greece from a perspective of cultural memory studies. ${ }^{39}$ She recalls how the Facebook group

37. "Vi kan altsaa paavise hvorledes Argos . . . allerede tidlig udmerkede sig ved bronceindustri og kunst og gik i spidsen for de græske kunstcentra ved omdannelse og græcisering af fra orienten optagne indflydelser" (ibid., 37).

38. "den skorpe af ukultur, som endnu for en stor del ligger over dem, er kun en naturlig følge af aarhundreders tryk og underkuelse" (ibid., 133).

39. Trine Stauning Willert, The New Ottoman Greece in History and Fiction: Modernity, Memory and Identity in South-East Europe (Cham: Springer, 2019). 
"Save the Ottoman Monuments of Greece" was met with aggressive and Islamophobic reactions that forced it to close down in 2016. But she also writes about how new academic trends are exploring the historical memory in Greece and, as a part of this, reinterpreting the place of the Ottoman past in Greek society today. In the introduction, Willert cites the Greek journalist Irini Kakoulidou as saying: "In Greece we have tried to delete the Ottoman period from our historical memory." ${ }^{40}$ Today's interest in the Ottoman heritage is a manner of problematizing the polarization between East and West, between Christianity and Islam that is in the core of all sorts of Orientalism and in European historiography of Southeastern Europe. As Willert points out, this dichotomic understanding has to be nuanced, since the period of the Tourkoukratia in Greece was multiethnic and multireligious, and left a multifarious heritage.

The Vergessenmachen of the Turkish presence in Greece is largely a heritage from philhellenic ideologies. It has been strengthened by the interplay between Greek nationalists and Western scholars and travelers. Just how powerful this tradition of forgetting was becomes clear when we return once again to the terra cotta horse in Sigrid Undset's novel, mentioned at the beginning of this essay. In her novel, it represented the promise of restored continuity with classical antiquity, mediated by the most famous and most "prototypical" of European archaeologists, Heinrich Schliemann. But her father, in From Akershus to the Acropolis, tells a completely different story about the origins of the figurine and the circumstances in which he acquired it: "From one of the small shopkeepers who had an open booth on the way up to the Acropolis, I bought a little horse figurine, painted with approximate Mycenaean varnish colors. It was said to have been found in a tomb in Melitos; and even if it was a forgery, as I now believe, there was no great damage done, since I paid only one drachma for it." ${ }^{41}$ Not a word about Schliemann - just a one-drachma forgery bought from a small shopkeeper in Athens! In a tradition that aimed at a forgetting of the intermediate layers of history, in order to create a line of transmission reaching back to classical antiquity and beyond, the classicizing autodidact Schliemann was, of course, a more welcome fellow than an Oriental shopkeeper on the slopes of the Acropolis.

40. Ibid., 4

41. "Hos en af de smaahandlere, der holder aaben bod ved veien op til Akropolis, kjøbte jeg en liden hestefigur, bemalet med omtrent mykenæiske fernisfarver; den skulde være funden i en grav ved Melite; selv om den skulde være falsk, hvad jeg nu tror, var dog skaden ei større, da jeg kun gav en drakme for den" (Undset, Fra Akershus til Akropolis, 131). 


\section{WORKS CITED}

\section{MANUSCRIPTS}

Undset, Ingvald. 1873. Georg Vilhelm Lyng: "Forelæsninger over den antike filosofis historie. I." Referert av Ingvald Undset. 1 b. 1873. Nasjonalbiblioteket. Privatsamlingen. Ms.forelesn. 676 n.d. Notatbok. Nasjonalbiblioteket. Privatsamlingen. Ms. $4^{0}$ 858:27.

\section{PRINT SOURCES}

About, Edmond. 1863. La Grèce contemporaine. Paris: Hachette.

Amadou, Christine, and Jorunn Økland, eds. 2019. From Akershus to Acropolis: Norwegian Travelers to Greece. Athens: Det norske institutt i Athen.

Andurand, Anthony. 2013. Le mythe grec allemand: Historie d'une affinité élective. Rennes: Presses Universitaires de Rennes.

Anon. 1896. "Undset, Ingvald Martin.” In Studenterne fra 1871, ved deres 25 Aars Jubiloum, 266-74. Christiania.

Barthélemy, Jean-Jacques. 1788. Le Voyage du jeune Anacharsis en Grèce, dans le milieu du quatrième siècle avant l'ère vulgaire. Paris: Chez De Bure l'aîné.

Basch, Sophie. 1995. Le mirage grec: La Grèce moderne devant l'opinion française (1846-1946). Athens: Kaufmann.

Borges, Jorge Luis. (1964) 2000. "Funes the Memorious." In Labyrinths: Selected Stories and Other Writings, translated by Donald Yates and James Irby, 87-95. London: Penguin.

Bugge, Christian. 1860. Fra Grokenland. Christiania: Jenssen.

Butler, E. M. 1935. The Tyranny of Greece over Germany. Boston: Beacon.

Byron, Lord. 1812. "Sons of the Greeks, Arise." In Childe Harold's Pilgrimage: A Romaunt; and Other Poems, 223-25. 4th ed. London: T. Davison.

Dascalakis, Apostolos. 1966 “The Greek Marseillaise of Rhigas Velestinlis.” Balkan Studies 7 (2): 273 96.

Deschamps, Gaston. 1894. La Grèce d'aujourd'hui. Paris: Armand Colin.

Dietrichson, Lorentz. 1876. Paa Studierejser: Albumblade og Optegnelser. Christiania: Cappelen.

Dimaras, C. Th. 1992. “Greece 1750-1850.” In Perceptions of the Ancient Greeks, edited by K. J. Dover, 203-25. Oxford: Blackwell.

Grivaud, Gilles. 2001. Les mishellénismes: Actes du séminaire organisé à l'École française d'Athènes (1618 mars 1998). Athens: École française d'Athènes.

Kasaba, Reşat. 2003. “The Enlightenment, Greek Civilization and the Ottoman Empire: Reflections on Thomas Hope's Anastasius.” Journal of Historical Sociology 16:1-21.

Koraïs, Adamantios. 1803. Mémoire sur l'état actuel de la civilisation dans la Grèce, lu à la Société des Observateurs de l'homme le 16 Nivôse, an xi. [Paris]: [Société des Observateurs de l'homme].

Marchand, Suzanne L. 1996. Down from Olympus: Archeology and Philhellenism in Germany, 17501970. Princeton, NJ: Princeton University Press.

Said, Edward. 1978. Orientalism: Western Conceptions of the Orient. London: Routledge.

Sande, Siri. 1997. "Ingvald Undset as a Collector of Antiquities." In Acta ad archeologiam et artium historiam pertinentia, edited by Laszlo Berczelly and J. Rasmus Brandt, 57-76. Rome: Giorgio Bretschneider editore.

Stamboulis, Giorgio. 2013. "The French Revolution and Greece: Four Pro-French Propaganda Writings of Korais.” Giornale di Storia costituzionale 25:203-22. 
Tolias, George 2016. “The Resilience of Philhellenism.” Historical Review/La Revue Historique 13:5172.

Tsigakou, Fani-Maria. 1981. The Rediscovery of Greece: Travellers and Painters of the Romantic Era. New York: Caratzas Brothers.

Undset, Ingvald. 1874. Den arkoeologiske kongres i Stockholm. Christiania: Cammermeyer.

—. 1880. Études sur l'âge de bronze de la Hongrie. Christiania: Cammermeyer.

1882. Das erste Auftreten des Eisens in Nord-Europa: Eine Studie in der vergleichenden vorhistorischen Archäologie. Translated by Johanna Mestorf. Hamburg: Otto Meisser.

- 1892. Fra Akershus til Akropolis. Christiania: Alb. Cammermeyers.

Undset, Sigrid. 1934. Elleve aar. Oslo: Aschehoug. Published in English as The Longest Years. Translated by Arthur G. Chater. New York: Knopf, 1935.

Wergeland, Henrik. 2008. "Nygræsk krigssang: Frit oversat" (ca. 1830). In Samlede skrifter 1, pt. 1. Oslo: Cappelen.

Willert, Trine Stauning 2019. The New Ottoman Greece in History and Fiction: Modernity, Memory and Identity in South-East Europe. Cham: Springer. 